\title{
Comparative AAPOS Validation of the blinq. Birefringent Amblyopia Screener with Isolated Small-Angle Strabismus [Response to Letter]
}

This article was published in the following Dove Press journal: Clinical Ophthalmology

\section{Robert W Arnold (D) \\ Pediatric Ophthalmology and Strabismus, Alaska Children's EYE \& Strabismus, Anchorage, Alaska 99508, USA}

Correspondence: Robert W Arnold Pediatric Ophthalmology and Strabismus, Alaska Children's EYE \& Strabismus, 3500 Latouche \#280, Anchorage, Alaska 99508, USA

Tel + I (907)56I-1917

$\mathrm{Fax}+\mathrm{I}(907) 563-5373$

Email eyedoc@alaska.net

\section{Dear editor}

Since I was first introduced to the amazing concept of bilateral birefringent screening championed by David G Hunter and David Guyton decades ago, I have been longing to try the technology on my patients so I purchased the blinq. ${ }^{\mathrm{TM}}$ device as soon as it became commercially available in late 2019 .

There are many steps that lead to successful community amblyopia reduction. We believe that early detection combined with thorough treatment is best. How early? Perhaps detection by age 1-2 years- long before reliable visual acuity screeningproduces the best lifetime vision. ${ }^{1}$ One important step in amblyopia reduction is reimbursement for quality screening. There is not yet a specific code for the unique kind of "photoscreening" blinq provides. My friend and founder of iScreen, Jack Bellows invested small fortune to get the current CPT that benefits all conventional photoscreening programs.

The American Academy of Pediatrics collaborates with pediatric ophthalmologists to endorse a series of age-appropriate screenings such that early screenings can be specific without perfect sensitivity as long as subsequent screenings are sensitive for amblyopia detection. High sensitivity can be achieved with patched, monocular visual acuity after age 4 years of age. Rebion blinq adds a new powerful weapon to be used strategically in the battle against childhood blindness.

In 2013 two important validation papers were published; 1) the AAPOS uniform guidelines paper ${ }^{2}$ that includes refractive amblyopia risk factors, but also strabismus, media opacity and defined amblyopia, and 2) David G Hunter's editorial that highlights devices that only detect amblyopia and/or strabismus. ${ }^{3}$ Amblyopia is defined by at least two components: 1) decreased visual acuity and 2) amblyopia risk factors. Two advantages of the AAPOS validation are uniformity and the ability to determine risk factors at very early ages. A disadvantage of Dr. Hunter's validation guideline is that visual acuity testing (for amblyopia definition) is not yet reliable until after age 3-4 years. Indeed, we find that several of our patients less than age 3 have trouble understanding how to gaze at blinq's tiny red smiley face fixation target, but children old enough for acuity testing yield more consistent blinq results. I anxiously await largescale validation of blinq performance in normal community preschool screening.

My study of blinq validated with 2013 AAPOS uniform guidelines ${ }^{4}$ shows that the birefringent scanner performs admirably as if it was a "regular" photoscreener. 
As such, I encourage pediatricians to utilize the existing photoscreening CPT code (99177) for blinq screening until a specialized birefringent scanning code becomes available.

\section{Disclosure}

The author coordinates the Alaska Blind Child Discovery that has received discounted vision screen technology from several vendors. He is an investigator and protocol developer for the NIH-supported Pediatric Eye Disease Investigator Group. He is the President of PDI Check which markets a vision screening game for the Nintendo 3DS autostereoscopic platform. He is also President of Glacier Medical Software which markets NICU cloudbased ROP Check software. The author reports no other conflicts of interest in this communication.

\section{References}

1. Kirk VG, Clausen MM, Armitage MD, Arnold RW. Preverbal photoscreening for amblyogenic factors and outcomes in amblyopia treatment: early objective screening and visual acuities. Arch Ophthalmol. 2008;126(4):489-492. doi:10.1001/archopht.126.4.489

2. Donahue SP, Arthur B, Neely DE, Arnold RW, Silbert D, Ruben JB. Guidelines for automated preschool vision screening: a 10-year, evidence-based update. J AAPOS. 2013;17(1):4-8. doi:10.1016/j. jaapos.2012.09.012

3. Hunter DG. Targeting treatable disease not just risk factors in pediatric vision screening. J AAPOS. 2013;17(1):2-3. doi:10.1016/j.jaapos. 2012.10.009

4. Arnold RW. Comparative AAPOS validation of the blinq birefringent amblyopia screener with isolated small-angle strabismus. Clin Ophthalmol. 2020;14:325-329. doi:10.2147/OPTH.S242335

Dove Medical Press encourages responsible, free and frank academic debate. The content of the Clinical Ophthalmology 'letters to the editor' section does not necessarily represent the views of Dove Medical Press, its officers, agents, employees, related entities or the Clinical Ophthalmology editors. While all reasonable steps have been taken to confirm the content of each letter, Dove Medical Press accepts no liability in respect of the content of any letter, nor is it responsible for the content and accuracy of any letter to the editor.

Clinical Ophthalmology

\section{Dovepress}

\section{Publish your work in this journal}

Clinical Ophthalmology is an international, peer-reviewed journal covering all subspecialties within ophthalmology. Key topics include: Optometry; Visual science; Pharmacology and drug therapy in eye diseases; Basic Sciences; Primary and Secondary eye care; Patient Safety and Quality of Care Improvements. This journal is indexed on PubMed
Central and CAS, and is the official journal of The Society of Clinical Ophthalmology (SCO). The manuscript management system is completely online and includes a very quick and fair peer-review system, which is all easy to use. Visit http://www.dovepress.com/ testimonials.php to read real quotes from published authors. 